\title{
Intensive expression of Bmi-1 is a new independent predictor of poor outcome in patients with ovarian carcinoma
}

\author{
Guo-Fen Yang ${ }^{1,2}$, Wei-Peng He², Mu-Yan Cai ${ }^{1}$, Li-Ru He${ }^{1}$, Jun-Hang Luo², Hai-Xia Deng ${ }^{1}$, Xin-Yuan Guan', \\ Mu-Sheng Zeng ${ }^{1}$, Yi-Xin Zeng ${ }^{1}$, Dan Xie ${ }^{1 *}$
}

\begin{abstract}
Background: It has been suggested that the B-cell specific moloney leukemia virus insertion site 1 (Bmi-1) gene plays an oncogenic role in several types of human cancer, but the status of Bmi-1 amplification and expression in ovarian cancer and its clinical/prognostic significance are unclear.

Methods: The methods of immunohistochemistry and fluorescence in situ hybridization were utilized to examine protein expression and amplification of Bmi-1 in 30 normal ovaries, 30 ovarian cystadenomas, 40 borderline ovarian tumors and 179 ovarian carcinomas.

Results: Intensive expression of Bmi-1 was detected in none of the normal ovaries, 3\% cystadenomas, 10\% borderline tumors, and 37\% ovarian carcinomas, respectively. Amplification of Bmi-1 was detected in $8 \%$ of ovarian carcinomas. In ovarian carcinomas, significant positive associations were found between intensive expression of Bmi-1 and the tumors ascending histological grade, later pT/pN/pM and FIGO stages $(P<0.05)$. In univariate survival analysis of the ovarian carcinoma cohorts, a significant association of intensive expression of Bmi-1 with shortened patient survival (mean 49.3 months versus 100.3 months, $p<0.001$ ) was demonstrated. Importantly, Bmi1 expression provided significant independent prognostic parameters in multivariate analysis $(p=0.005)$.
\end{abstract}

Conclusions: These findings provide evidence that intensive expression of Bmi-1 might be important in the acquisition of an invasive and/or aggressive phenotype of ovarian carcinoma, and serve as a independent biomarker for shortened survival time of patients.

\section{Background}

Ovarian cancer is a major lethal gynecological malignancy worldwide [1]. Its peak incidence is at the age 45 or above. Because of its insidious onset, approximately $70 \%$ of ovarian cancer patients were diagnosed at advanced stage(FIGO III/IV stage) with a very poor prognosis, whose 5-year survival rate is of $<30 \%$ [2]. Ovarian carcinoma is the most common histopathological type of ovarian cancer. The development and progression of ovarian carcinoma are presumed to be a multi-step process involving multiple genetic changes [3]. Thus, a substantial amount of research on ovarian carcinoma has focused on the discovery of specific

\footnotetext{
* Correspondence: xied@mail.sysu.edu.cn

${ }^{1}$ State Key Laboratory of Oncology in South China, Cancer Center, Sun YatSen University, No. 651, Dongfeng Road East, 510060 Guangzhou, China
}

molecular markers that are present in ovarian carcinoma cells which could serve as reliable prognostic factors.

The B-cell specific moloney leukemia virus insertion site 1 (Bmi-1) gene belongs to mammalian Polycombgroup (PcG) family forming multimeric gene-repressing complexes involved in axial patterning, hematopoiesis, regulation of proliferation, and senescence. Bmi-1 was first identified as a proto-oncogene that cooperated with $\mathrm{c}-\mathrm{Myc}$ in generating pre-B-cell lymphomas in a murine model [4-8]. It has been discovered that Bmi-1 participates in cell cycle regulation by acting as a stable transcriptional repressor of the Ink4a locus, which encodes the tumor suppressor proteins p16Ink4a and p19Arf (mouse homologue of human p14ARF). Inactivation of the p16Ink4a-pRb pathway and p14ARF-MDM2-p53 pathway by Bmi-1 deregulation has been clearly
Ciomed Central 
implicated in lymphomagenesis $[9,10]$ and oncogenesis in nonsmall-cell lung cancer of human [11]. This suggested that the Bmi-1 gene plays an important role in cell proliferation and tumor progression. It has been confirmed that $B m i-1$ gene is widely expressed in diverse human tumors, including non-small cell lung cancer, hepatocellular carcinoma, B-cell non-Hodgkin's lymphoma, breast cancer, ovarian cancer, colorectal cancer, skin cancer and neuroblastoma [10-20], and has been shown to be a useful prognostic marker in myelodysplastic syndrome and many cancers, including nasopharyngeal carcinoma, bladder cancer and gastric cancer [17-20].

To date, however, the status of Bmi-1 expression and its clinical/prognostic relevance in ovarian cancer have not been fully elucidated. In this study, the protein expression and amplification status of Bmi-1 in a series of human epithelial ovarian tissue, normal and pathological, non-neoplastic and neoplastic, were examined. The clinico-pathological and prognostic significance of expression of Bmi-1 in our ovarian carcinoma cohorts was also assessed.

\section{Methods}

\section{Patients and tissue specimens}

In this study, a total of 249 epithelial ovarian tumors (benign, borderline and carcinomatous) were obtained from archives of paraffin-embedded tissues between 1996 and 2008 at the Department of Pathology, Cancer Center and the First Affiliated Hospital, Sun Yat-Sen University, Guangzhou, China. The cancer cases selected were based on availability of resection tissue and followup data. Patients whose cause of death remained unknown were excluded from our study. The ovarian tumor cases encompassed 179 histologically confirmed invasive carcinomas, 40 borderline tumors and 30 cystadenomas. Data of survival time and clinico-pathological parameters were collected. Ages of the 179 patients with ovarian carcinoma ranged from 18 to 86 years (mean age, 50.7 years) and their clinico-pathological characteristics are summarized in Table 1 . None of the cancer patients in this study had received preoperative radiation or chemotherapy. In addition, 30 specimens of normal ovaries from exairesis for non-ovary diseases in the Department of Gynaecology and Obstetrics of the First Affiliated Hospital, Sun Yat-Sen University from 2005 to 2008 were used as control. For the use of these clinical materials for research purposes, prior patient's consent and approval from the Institute Research Medical Ethics Committee of Sun Yat-Sen University was obtained.

\section{Construction of tissue microarrays (TMA)}

The TMA was constructed according to a method described previously [21]. Briefly, the individual donor tissue block and the corresponding histological H\&E stained slides were overlaid for tissue TMA sampling. The tissues (179 ovarian carcinoma, 40 borderline tumor, and 30 cystadenoma tissues) were sampled using a tissue arraying instrument (Beecher Instruments, Silver Spring, MD); a 0.6-mm-diameter cylinder of tissue was removed. Subsequently, the tissue cylinder was reembedded into a predetermined position in a recipient paraffin block. In our constructed ovarian tumor tissueTMA, 3 cores of sample were selected from each tumor tissue. Multiple sections ( $5 \mu \mathrm{m}$ thick) were cut from the TMA block and mounted on microscope slides.

\section{Immunohistochemistry (IHC)}

IHC studies were performed using a standard streptavidin-biotin-peroxidase complex method [22]. For antigen retrieval, tissue slides were microwave-treated and boiled in a $10 \mathrm{mM}$ citrate buffer $(\mathrm{pH} \mathrm{6.0)}$ for $10 \mathrm{~min}$. The slides were incubated with rabbit monoclonal antibody against human Bmi-1 (Shangying Biotechnology Inc. Wuhan, China, 1:2000 dilution), mouse monoclonal antibodies against human p16Ink4a (1:200 dilution) or p14ARF (1:300 dilution, Labvision Co., Neomarkers, USA) overnight at $4^{\circ} \mathrm{C}$ in a moist chamber. A negative control was obtained by replacing the primary antibody with normal rabbit or mouse IgG. Known immunostaining positive slides were used as positive controls.

Expression levels of Bmi-1 protein were visualized by observing the stained tissues under a light microscope. Positive expression of Bmi-1 was defined as the presence of brown or yellowish brown granules in the nuclei, though occasionally yellowish brown granules could also be seen in the cytoplasm. For evaluation of the Bmi-1 IHC staining in different ovarian tissues, a semi-quantitative scoring criterion for IHC of Bmi-1 described previously [16] was used, in which both staining intensity and positive areas were recorded. A staining index (values 1 to 16), obtained as the intensity of Bmi-1 positive staining (negative $=1$, weak $=2$, moderate $=3$, or strong $=4$ scores) and the proportion of immunopositive cells of interest $(\leq 10 \%=1,>10 \%$ to $\leq 50 \%=2$, $>50 \%$ to $\leq 75 \%=3,>75 \%=4$ scores) were calculated. The two different scores of corresponding sample were then multiplied. Points equal or less than 4 was marked as $(-) ; 4$ points to 8 points was marked as $(+) ; 8$ points to 12 points, $(++)$; and 12 points to 16 points, $(+++)$. For statistical analysis, $(-)$ and $(+)$ were counted as low expression of Bmi-1 (Fig. 1A, B and 1C), while $(++)$ and $(+++)$ were counted as intensive expression of Bmi-1 (Fig. 1D and 1E). The evaluation of p16Ink4a and p14ARF IHC staining was scored on a semi-quantitative scale [14], as follows: negative expression $(<10 \%$ of the cells were positive), down-regulated expression (small cell clusters, but $10-50 \%$ of the cells were positive) and 
Table 1 Association of Bmi-1 expression with patient's clinico-pathological features in ovarian carcinomas

\begin{tabular}{|c|c|c|c|c|}
\hline & \multirow[b]{2}{*}{ All cases } & \multicolumn{3}{|l|}{ Bmi-1 protein } \\
\hline & & Low expression & Intensive expression & $P$ value $^{\mathrm{a}}$ \\
\hline Age at surgery (years) & & & & 0.452 \\
\hline$\leq 50.7^{\mathrm{b}}$ & 92 & $60(65 \%)$ & $32(35 \%)$ & \\
\hline$>50.7$ & 87 & $52(60 \%)$ & $35(40 \%)$ & \\
\hline Histological type & & & & 0.038 \\
\hline Serous (grade 1) & 11 & $9(82 \%)$ & $2(18 \%)$ & \\
\hline Serous (grade2/3) & 107 & $68(64 \%)$ & $39(36 \%)$ & \\
\hline Mucinous & 23 & 15 (65\%) & $8(35 \%)$ & \\
\hline Endometrioid & 8 & $7(88 \%)$ & $1(12 \%)$ & \\
\hline Clear cell & 7 & $5(71 \%)$ & $2(29 \%)$ & \\
\hline Undifferentiated & 23 & $8(35 \%)$ & $15(65 \%)$ & \\
\hline Histological grade (Silveberg) & & & & 0.011 \\
\hline G1 & 36 & $29(81 \%)$ & $7(19 \%)$ & \\
\hline G2 & 101 & $63(62 \%)$ & $38(38 \%)$ & \\
\hline G3 & 42 & $20(48 \%)$ & $22(52 \%)$ & \\
\hline pT status & & & & 0.037 \\
\hline pT1 & 51 & $39(76 \%)$ & $12(24 \%)$ & \\
\hline pT2 & 35 & $22(63 \%)$ & $13(37 \%)$ & \\
\hline pT3 & 93 & $51(55 \%)$ & $42(45 \%)$ & \\
\hline pN status & & & & 0.001 \\
\hline pNO & 88 & 66 (75\%) & $22(25 \%)$ & \\
\hline pN1 & 91 & 46 (51\%) & 45 (49\%) & \\
\hline pM status & & & & 0.006 \\
\hline $\mathrm{pMX}$ & 153 & 102 (67\%) & 51 (33\%) & \\
\hline $\mathrm{pM} 1$ & 26 & 10 (38\%) & $16(62 \%)$ & \\
\hline FIGO stage & & & & 0.002 \\
\hline I & 33 & 27 (82\%) & $6(18 \%)$ & \\
\hline$\|$ & 21 & 17 (81\%) & $4(19 \%)$ & \\
\hline III & 99 & 58 (59\%) & 41 (41\%) & \\
\hline IV & 26 & 10 38\%) & 16 (62\%) & \\
\hline
\end{tabular}

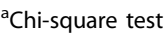

${ }^{\mathrm{b}}$ Mean age

diffuse expression ( $>50 \%$ of the cells were positive). Results were observed and assessed by two independent pathologic doctors, without knowing the identity of the samples.

\section{Fluorescence in situ hybridization (FISH)}

Two-color FISH was performed using a Spectrum Orange-labeled BAC clone (RP11-573G6) at 10p12 containing the Bmi-1 gene and a Spectrum Green-labeled reference centromeric probe on chromosome 10 (Vysis, Downers Grove, IL). The FISH reaction was performed as described previously [23] with slight modification. Briefly, deparaffinized ovarian carcinoma tissue sections were treated with proteinase $\mathrm{K}(400 \mu \mathrm{g} / \mathrm{ml})$ at $37^{\circ} \mathrm{C}$ for $30 \mathrm{~min}$, followed by denaturing in $70 \%$ formamide, $2 \times$ $\mathrm{SSC}$ at $75^{\circ} \mathrm{C}$ for $6 \mathrm{~min}$. Fifty nanograms of each probe were mixed in a $20 \mu \mathrm{l}$ hybridization mixture (containing $55 \%$ formamide, $2 \times \mathrm{SSC}$, and $2 \propto \mathrm{g}$ human Cot1 DNA), denatured at $75^{\circ} \mathrm{C}$ for 6 min and then hybridized to the denatured tissue sections at $37^{\circ} \mathrm{C}$ for 24 hours. The slides were counterstained with $1 \mu \mathrm{g} / \mathrm{ml}$ DAPI in an anti-fade solution and were examined with a Zeiss Axiophot microscope equipped with a triple-band pass filter. A minimum of 300 tumor cells was evaluated per specimen. Amplification of Bmi-1 was defined as presence of either 6 (or more) Bmi-1 gene signals or at least 3 times as many gene signals than centromere signals of chromosome 10 in tumor cells (Fig. 1F).

\section{Statistical analyses}

Statistical analysis was carried out with the SPSS statistical software package (SPSS Standard version 13.0, SPSS Inc.). The association of Bmi-1 protein expression with ovarian carcinoma patient's clinico-pathological features was assessed by the Chi-square test. Multivariate survival analysis was performed on all parameters that were 


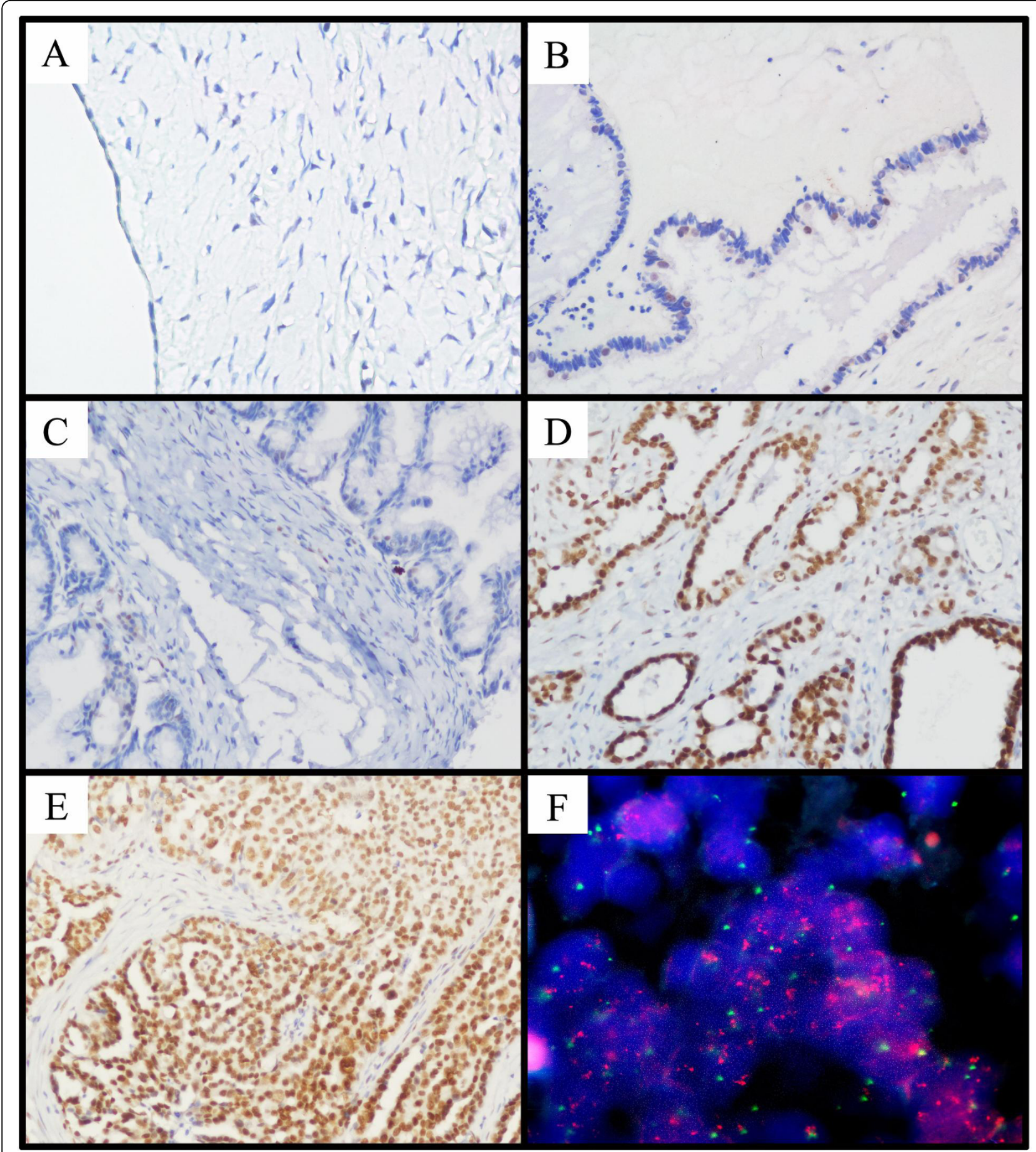

Figure 1 Immunohistochemical staining of Bmi-1 protein and Fluorescence in situ hybridization of Bmi-1 gene in human ovarian tissues. (A) Negative expression of Bmi-1 was observed in a normal surface epithelium of ovary (200X). (B) An ovarian cystadenoma showed low expression of Bmi-1, in which about 10\% of tumor cells was detected moderate positive staining of Bmi-1 (200x). (C) Low expression of Bmi-1 was observed in an borderline ovarian tumors, in which 5\% of tumor cells showed weak positive staining of Bmi-1 (200x). (D) Intensive expression of Bmi-1 was detected in an ovarian carcinoma (case 33), in which more than $90 \%$ of carcinoma cells showed strong positive staining of Bmi-1 (200x). (E) Another ovarian carcinoma (case 161) showed intensive expression of Bmi-1, in which all of tumor cells had strong positive staining of Bmi-1 (200X). (F) Amplification of Bmi-1 gene was observed by FISH in the same ovarian carcinoma case (161), in which Bmi-1 gene signals (red) was detected at least 3 times more than centromere signals of chromosome 10 (green) (1000x). 
found to be significant on univariate analysis using the Cox regression model. For univariate survival analysis, we analyzed all ovarian carcinoma patients by Kaplan-Meier analysis. Log rank test was used to compare different survival curves. $P<0.05$ was considered significant.

\section{Results}

\section{Bmi-1 expression in ovarian tissues}

Bmi-1 expression could be evaluated informatively in TMA tissues of 163/179 of ovarian carcinomas, 37/40 of borderline tumors and 26/30 of cystadenomas. The noninformative TMA samples included unrepresentative samples, samples with too few tumor cells $(<300$ cells per case) and lost samples. IHC staining of such noninformative samples were replaced and performed by using whole tissue slides. In our study, we defined that $(-)$ and $(+)$ were counted as low expression of Bmi-1, while $(++)$ and $(+++)$ were counted as intensive expression of Bmi-1. According to this definition, the intensive expression of Bmi-1 was detected in 67/179 (37\%) ovarian carcinomas. The increasing frequencies of Bmi-1 intensive expression in normal ovarian epithelium (0), to benign cystadenomas (3\%), to borderline tumors $(10 \%)$, and to invasive carcinomas were significant $(37 \%, P<$ 0.05, Table 2).

\section{Association of Bmi-1 expression with ovarian carcinoma patient clinico-pathologic features}

The association between Bmi-1 expression in ovarian carcinomas and several known clinico-pathological features was further studied. Bmi-1 expression was positively correlated with tumors histological type, grade, $\mathrm{pT} / \mathrm{pN} / \mathrm{pM}$ status, and FIGO stage $(P<0.05$, Table 2$)$. No significant correlation was obtained between Bmi-1 expression and patient age ( $\leq 50.7$ years $v s>50.7$ years) $(P>0.05$, Table 1$)$.

Relationship between clinicopathologic variables, Bmi-1 expression and ovarian carcinoma patient survival: Univariate survival analysis

In univariate survival analyses, cumulative survival curves were calculated according to the Kaplan-Meier

Table 2 The expression of Bmi-1 in normal ovaries and in benign and malignant epithelial ovarian tumors ${ }^{a}$

\begin{tabular}{lccc}
\hline & \multicolumn{3}{c}{ Bmi-1 protein } \\
\cline { 2 - 4 } & All cases & Low expression & Intensive expression \\
\hline Normal ovaries & 30 & $30(100 \%)$ & $0(0)$ \\
Cystadenomas & 30 & $29(97 \%)$ & $1(3 \%)$ \\
Borderline tumors & 40 & $36(90 \%)$ & $4(10 \%)$ \\
Invasive carcinomas & 179 & $112(63 \%)$ & $67(37 \%)$
\end{tabular}

${ }^{a}$ Values are $\mathrm{n}(\%)$. A significant increasing frequency of intensive expression of Bmi-1 was observed in cystadenomas, in borderline tumors and in invasive carcinomas $(P<0.01$, Chi-Square Test for Trend) method. Differences in survival times were assessed with the log-rank test. First, to confirm the representativeness of the ovarian carcinomas in our study, we analyzed established prognostic predictors of patient survival. Kaplan-Meier analysis demonstrated a significant impact of well-known clinical pathological prognostic parameters, such as tumor histological grade $(p=0.012)$, $\mathrm{pT} / \mathrm{pN} / \mathrm{pM}$ status $(p<0.01)$ and FIGO stage $(p<0.001)$ on patient survival (Table 3 ). The mean survival time for patients with tumors having intensive expression of Bmi-1 was 49.3 months compared to 100.3 months for pateints with tumors having low expression of Bmi-1

Table 3 Clinical pathological parameters and expression of Bmi-1 for prognosis of 179 patients with ovarian carcinoma by univariate survival analysis (log-rank test)

\begin{tabular}{|c|c|c|c|c|}
\hline Variable & $\begin{array}{c}\text { All } \\
\text { cases }\end{array}$ & $\begin{array}{c}\text { Mean } \\
\text { survival } \\
\text { (months) }\end{array}$ & $\begin{array}{c}\text { Median } \\
\text { survival } \\
\text { (months) }\end{array}$ & $\begin{array}{c}P \\
\text { value }\end{array}$ \\
\hline Age at surgery (years) & & & & 0.388 \\
\hline$\leq 50.7^{a}$ & 92 & 83.4 & 136.0 & \\
\hline$>50.7$ & 87 & 81.7 & 55.0 & \\
\hline Histological type & & & & 0.491 \\
\hline Serous(grade 1) & 11 & 110.4 & 136.0 & \\
\hline Serous(grade2/3) & 107 & 63.4 & 52.0 & \\
\hline Mucinous & 23 & 75.8 & $N R^{b}$ & \\
\hline Endometrioid & 8 & 116.7 & NR & \\
\hline Clear cell & 7 & 102.8 & NR & \\
\hline Undifferentiated & 23 & 32.7 & NR & \\
\hline $\begin{array}{l}\text { Histological grade } \\
\text { (Silveberg) }\end{array}$ & & & & 0.012 \\
\hline G1 & 36 & 104.9 & 136.0 & \\
\hline G2 & 101 & 85.9 & 64.0 & \\
\hline G3 & 42 & 48.0 & 29.0 & \\
\hline pT status & & & & 0.003 \\
\hline pT1 & 51 & 109.5 & NR & \\
\hline pT2 & 35 & 82.2 & NR & \\
\hline pT3 & 93 & 66.5 & 35.0 & \\
\hline pN status & & & & $<0.001$ \\
\hline $\mathrm{pNO}$ & 88 & 100.9 & 136.0 & \\
\hline pN1 & 91 & 52.8 & 28.0 & \\
\hline pM status & & & & $<0.001$ \\
\hline $\mathrm{pMX}$ & 153 & 94.8 & 136.0 & \\
\hline pM1 & 26 & 21.5 & 9.0 & \\
\hline FIGO stage & & & & $<0.001$ \\
\hline 1 & 33 & 134.2 & NR & \\
\hline$\|$ & 21 & 115.0 & NR & \\
\hline III & 99 & 71.5 & 37.0 & \\
\hline IV & 26 & 21.5 & 9.0 & \\
\hline Bmi-1 expression & & & & $<0.001$ \\
\hline Low & 112 & 100.3 & 136.0 & \\
\hline Intensive & 67 & 49.3 & 22.0 & \\
\hline
\end{tabular}

a Mean age

${ }^{\mathrm{b}}$ Not reached 


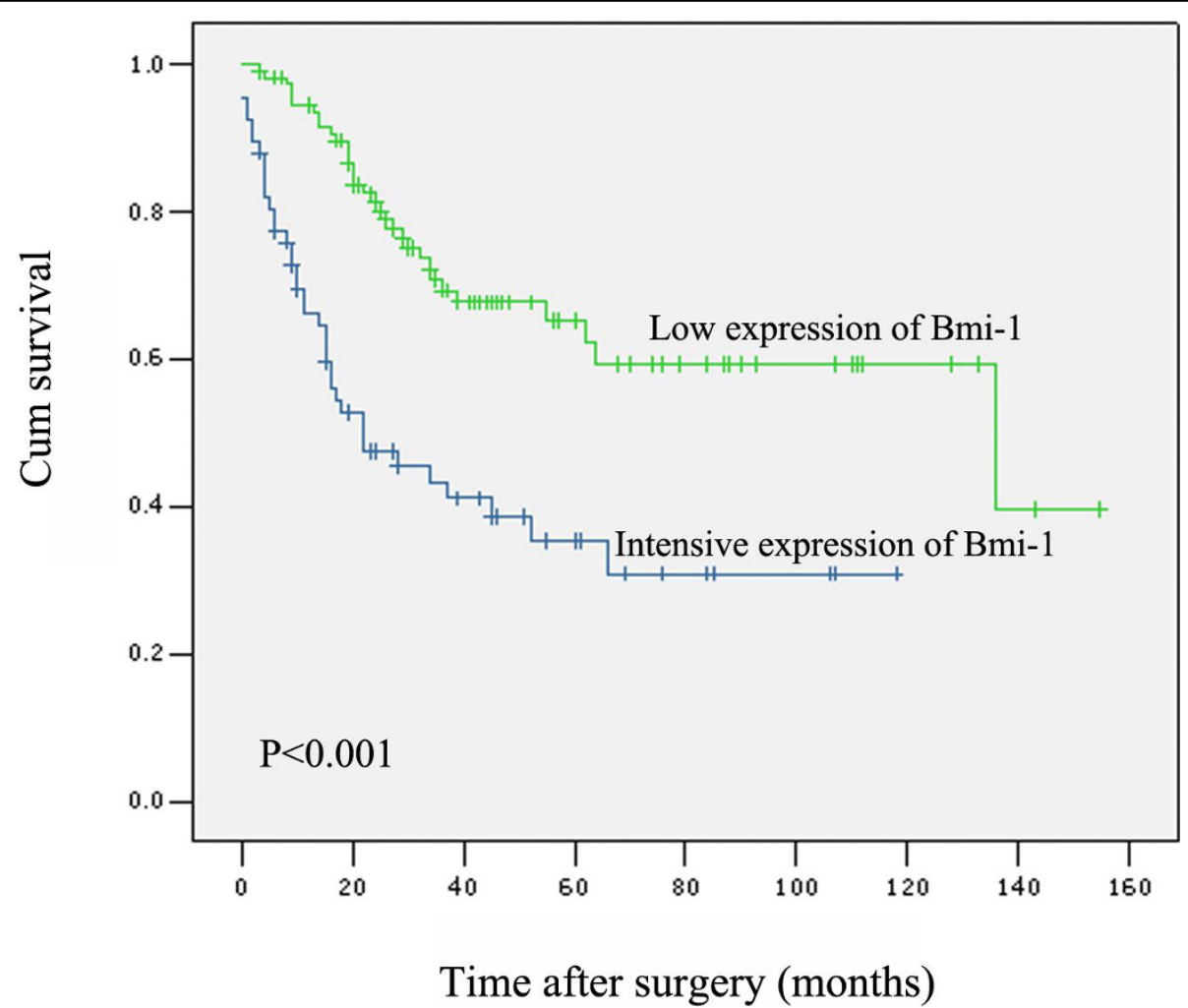

Figure 2 Kaplan-Meier survival analysis according to Bmi-1 expression in 179 patients with invasive ovarian carcinoma (log-rank test) Probability of survival of patients: low expression of Bmi-1, $n=112$; intensive expression of Bmi-1, $n=67(p<0.001)$.

$(P<0.001$, Fig. 2, Table 3). In stratified survival analysis, Bmi-1 expression could stratify the outcome of patients in hige-grade (grade $2 / 3)$ serous carcinoma $(P=0.045)$, mucinous carcinoma $(P=0.001)$ and undifferentiated carcinoma $(P=0.001)$ subgroups.

\section{Independent prognostic factors of ovarian carcinoma: Multivariate Cox regression analysis}

Since variables observed to have prognostic influence by univariate analysis may covariate, the expression of Bmi1 as well as other clinical pathological parameters that were significant in univariate analysis ( $\mathrm{pN}$ stage and FIGO stage) was examined in multivariate analysis (Table 4). The expression of Bmi-1 was found to be an independent prognostic factor for poor overall survival (relative risk: $1.998, \mathrm{CI}: 1.228-3.251, P=0.005)$. Of the other parameters, $\mathrm{pN}$ stage $(P=0.010)$ and FIGO stage $(P=0.004)$ were also demonstrated as independent prognostic factor for overall survival.

\section{Amplification of Bmi-1 in ovarian tumor TMA}

In our FISH study, the FISH analysis was informative in 96/179 of ovarian carcinomas, 21/40 of borderline ovarian tumors and 15/30 of ovarian cystadenomas. Samples without FISH signal and samples with weak target signals
Table 4 Multivariate analysis on overall survival (Cox regression model)

\begin{tabular}{lccc}
\hline Variable & Relative risk & 95\% Confidence interval & $\boldsymbol{P}$ value \\
\hline Bmi- $^{\mathrm{a}}$ & 1.998 & $1.228-3.251$ & 0.005 \\
Histological grade $^{\mathrm{b}}$ & 0.940 & $0.614-1.439$ & 0.777 \\
pT status $^{\mathrm{c}}$ & 1.189 & $0.788-1.793$ & 0.409 \\
pN status $^{\mathrm{d}}$ & 2.016 & $1.184-3.432$ & 0.010 \\
pM status $^{\mathrm{e}}$ & 0.975 & $0.280-3.393$ & 0.975 \\
FIGO stage $^{\mathrm{f}}$ & 3.686 & $1.521-8.931$ & 0.004 \\
\hline
\end{tabular}

${ }^{\mathrm{a}}$ Intensive expressin vs Low expression

${ }^{\mathrm{b}} \mathrm{G} 1$ vs $\mathrm{G} 2$ vs $\mathrm{G} 3$

cpT1 vs PT2 vs pT3

dpNO vs pN1

epMX vs pM1

${ }^{\mathrm{f}}$ Stage I vs Stage II vs Stage III vs StagelV

or those with a strong signal background were the main reasons for most of the non-informative cases. FISH results demonstrated that the amplification of Bmi-1 was not detected in any of the ovarian cystadenoma and borderline tumor tissues; but was detected in $8 \%(8 / 96)$ of the informative ovarian carcinomas; in each of the 8 cases with Bmi-1 amplification, intensive expression of Bmi-1 was observed (Fig. 1E and 1F). In the remaining 88 informative cancers without amplification of Bmi-1, 
$60(68 \%)$ cases showed low expression of Bmi-1, while 28 (32\%) cases were observed intensive expression of Bmi-1.

\section{Correlation between the expression of Bmi-1 and p16Ink4a and p14ARF in ovarian carcinomas}

Since it was suggested that modulation of Bmi-1 protein might be involved in human colorectal carcinogenesis by repressing $\mathrm{p} 16 \mathrm{Ink} 4 \mathrm{a} / \mathrm{p} 14 \mathrm{ARF}$ proteins $\{14\}$, we further examined the expression of p16Ink4a/p14ARF by IHC in our ovarian carcinoma cohorts. By utilizing the criterion of a semi-quantitative scale as previously described [14], we found that $36 \%(64 / 179)$ and $17 \%$ (30/179) of ovarian carcinomas had negative/down-regulated expression of p16Ink4a and p14ARF, respectively. Further correlation analysis demonstrated that no significant correlation between Bmi-1 expression and expression of either p16Ink4a or p14ARF was evaluated in these ovarian carcinoma cohorts $(P>0.05$, Fishers exact test).

\section{Discussion}

In recent years, the incidence of ovarian carcinoma has been increasing in Asian countries such as China and Singapore [24]. The available clinicopathologic prognostic indicators are not accurate, although the treatment of ovarian cancer has been improved greatly in recent years, its 5 -year survival rate is of $<30 \%$ [2]. Thus, it is important to identify a biological genetic molecular marker that is associated with pathophysiologic processes of human ovarian cancer.

The gene, Bmi-1, was initially shown to regulate haematopoiesis and differentiation of lymphocytes [25] and to be involved in cerebral development [26]. To date, the proto-oncogene Bmi-1 has been reported to be upregulated in a large number of neoplasias, namely in lymphomas [27], cerebral tumours [26], breast cancer [13] and other epithelial tumours [28,29] and to be an oncogene associated with poor prognosis in various tumours [12]. To investigate whether or not the abnormal expression of Bmi-1 is involved in the pathogenesis of ovarian carcinoma, in the present study, the protein expression of Bmi-1 was examined firstly by IHC in normal ovaries, benign and borderline epithelial ovarian tumors, and malignant epithelial cancers. The results demonstrated that the expression of Bmi-1 in all of the normal ovary specimens was absent or at low levels. In our ovarian tumor specimens, a significant increasing expression of Bmi-1 was observed from benign cystadenoma to borderline tumor, and to carcinoma. In addition, we found that the frequency of intensive expression of Bmi-1 in undifferentiated ovarian carcinomas was significantly larger than that in other types of carcinoma. In serous carcinomas, intensive expression of Bmi-1 was more likely to be observed in grade $2 / 3$ tumors than that in grade 1 tumors. Furthermore, intensive expression of $\mathrm{Bmi}-1$ in our ovarian carcinoma cohorts was strongly correlated with an ascending histological grade and clinical stage $(\mathrm{pT} / \mathrm{pN} / \mathrm{pM}$ and FIGO stage) of the tumor. These findings suggest that upregulated expression of Bmi-1 in ovarian carcinoma may represent an acquired malignant phenotypic feature of tumor cells.

Datas from several clinical studies show that abnormal expression of Bmi-1, in protein level as well as in gene level, is favorably associated with poor prognostic markers and clinical outcome in diverse human cancers, such as colorectal cancer, nasopharyngeal carcinoma, bladder cancer and myelodysplastic syndrome [14,17-19]. However, to our best knowledge, there is little information about prognostic status and clinical outcome of Bmi-1 expression in ovarian cancer. This is the first study evaluating the expression of $B m i-1$ by IHC, in association with clinicopathological and prognostic significance for a large number of ovarian cancer patients. Consistent with previous reports of other types of human cancer, in this study, we found that intensive expression of Bmi-1 in ovarian carcinoma was a predictor of short overall survival, independent of stage and grade. These findings raise the question of a potentially why important role of Bmi-1 as an underlying biological mechanism in the development and/or growth of human cancers.

It is known, the encoded protein of $B m i-1$, as well as other proteins from the PcG family, can block the transcription of some genes such as p16Ink4a and p19Arf involved in tumour suppression, resulting in oncogenic effects [14]. In our previous investigation, however, we found that Bmi-1 may promote immortalization of nasopharyngeal carcinoma by modulating the expression of other genes, besides regulating p16Ink4a. Also, in the present study, we did not observe a significant correlation between Bmi-1 expression and either p16Ink4a or p14ARF expression in ovarian carcinoma cohorts. This data provided evidence that Bmi-1 does act through other molecular targets than repression of p16Ink4a/ p14ARF in ovarian carcinogenesis. Recently, it was reported that by applying a mouse/human comparative translational genomics approach, a Bmi-1-driven 11gene signature was identified. This cohort of 11 genes was confirmed to be a magic marker of stem cell-ness and therapy failure in patients with a variety of aggressive tumors [18]. Clearly, further work needs to be done to more precisely understand the molecular mechanism of $B m i-1$ in the development and progression of ovarian carcinoma, as well as other human cancers.

With regard to the mechanism of up-regulated protein expression of Bmi-1 in ovarian carcinomas, it is known that gene amplification is a common pathological 
mechanism of gene overexpression in human cancers [30]. To determine whether the overexpression of Bmi-1 in ovarian carcinomas was caused by gene amplification, the amplification status of $B m i-1$ was examined by FISH. In our 96 informative cases of ovarian carcinomas by both IHC and FISH simultaneously, intensive expression of $B m i-1$ was detected in all (8/8) ovarian carcinomas that had Bmi-1 amplification. However, amplification of Bmi-1 was not observed in 28 other ovarian carcinomas with intensive expression of Bmi-1. These results indicate that the expression level of Bmi-1 protein in ovarian carcinoma does not always coincide with gene amplification. In addtion, in bladder cancers, a significant difference in Bmi-1 protein expression and in mRNA levels was obtained, but Bmi-1 protein was up-regulated to a much greater extent than Bmi-1 mRNA in cancer tissue compared with non-cancerous tissues, implying that the major source of Bmi-1 expression might be dysregulation at the post-transcriptional level in bladder cancers [19]. These data suggest that the up-regulation of protein expression of Bmi-1 in human cancers is complicated and it might be regulated not only by gene amplification, but also by other molecular mechanisms including transcriptional regulation and post-translational regulation.

\section{Conclusion}

In summary, in this study, we describe, for the first time, protein expression and amplification patterns of Bmi-1 in normal human ovary, benign, borderline and malignant epithelial ovarian tumor tissues. Our results provide a basis for the concept that increased expression of Bmi-1 in human ovarian carcinoma may be important in the acquisition of an invasive and/or aggressive phenotype. In addition, our study introduces Bmi-1 expression as a new independent prognostic marker in ovarian carcinoma with intensive expression of Bmi-1 protein in tumor cells predicting poor outcome of the disease for the individual patient.

\section{Acknowledgements}

This study was supported by the grants from the the Major State Basic Research Program of China (2006CB910104), the Nature Science Foundation of China (No.30772334) and Project of Guangdong Science and Technology Agency (No. 2004B35001004 and 2005A30801001).

\section{Author details}

${ }^{1}$ State Key Laboratory of Oncology in South China, Cancer Center, Sun YatSen University, No. 651, Dongfeng Road East, 510060 Guangzhou, China.

${ }^{2}$ Department of Gynecology, the First Affiliated Hospital, Sun Yat-Sen University, No. 78, Zhongshan Road II, 510080 Guangzhou, China.

\section{Authors' contributions}

GFY evaluated the clinical records and drafted the manuscript. WPH carried out the immunohistochemistry assays and help to draft the manuscript. MYC participated in the statistical analysis and participated in its coordination. HLR performed the immunohistochemical analyses. JHL and
HXD help to carry out the immunohistochemistry assays. XYG, MSZ, YXZ and DX participated in the design of the study, in its analysis and in the interpretation of the data. DX designed the study and also participated in evaluated the immunohistochemistry results and wrote the manuscript. All authors read and approved the final manuscript.

\section{Competing interests}

The authors declare that they have no competing interests.

Received: 12 October 2009 Accepted: 8 April 2010

Published: 8 April 2010

\section{References}

1. Wingo PA, Ries LA, Rosenberg HM, Miller DS, Edwards BK: Cancer incidence and mortality. 1973-1995, a report card for the U.S. Cancer 1998, 82:1197-207.

2. Freund KM, Dolan NC, Nelson HD: Update in women's health. Ann Int Med 2003, 138:119-127.

3. DiSaia PJ, Bloss JD: Treatment of ovarian cancer: new strategies. Gynecol Oncol 2003, 90:S24-32.

4. van Lohuizen M, Frasch M, Wientjens E, Berns A: Sequence similarity between the mammalian bmi-1 proto-oncogene and the Drosophila regulatory genes Psc and Su(z)2. Nature 1991, 353:353-355.

5. Haupt $Y$, Bath ML, Harris AW, Adams JM: Bmi-1 transgene induces lymphomas and collaborates with myc in tumorigenesis. Oncogene 1993, 8:3161-3164.

6. Jacobs JJ, Kieboom K, Marino S, DePinho RA, van Lohuizen M: The oncogene and Polycomb-group gen bmi- 1 regulates cell proliferation and senescence through the ink4a locus. Nature 1999, 397:164-168.

7. Lugt NM, Domen van der J, Linder sK, van Roon M, Robanus-Maandag E, te Riele H, Valk M, Deschamps van der J, Sofroniew M, van Lohuizen M: Posterior transformation, neurological abnormalities, and severe hematopoietic defects in mice with a targeted deletion of the bmi-1 pro-oncogene. Genes Dev 1994, 8:757-769.

8. Lessard J, Sauvageau G: Bmi-1 determines the proliferative capacity of normal and leukaemic stem cells. Nature 2003, 423:255-60.

9. Lindstrom MS, Klangby U, Wiman KG: P14ARF homozygous deletion or MDM2 overexpression in Burkitt lymphoma lines carrying wild type p53. Oncogene 2001, 20:2171-7.

10. Bea S, Tort F, Pinyol M, Puig X, Hernandez L, Hernandez S, Fernandez PL, van Lohuizen M, Colomer D, Campo E: Bmi-1 gene amplification and overexpression in hematological malignancies occur mainly in mantle cell lymphomas. Cancer Res 2001, 61:2409-12.

11. Vonlanthen S, Heighway J, Altermatt HJ, Gugger M, Kappeler A, Borner MM, van Lohuizen M, Betticher DC: The bmi-1 oncoprotein is differentially expressed in non-small cell lung cancer and correlates with INK4A-ARF locus expression. Br J Cancer 2001, 84:1372-6.

12. van Kemenade FJ, Raaphorst FM, Blokzijl T, Fieret E, Hamer KM, Satijn DP, Otte AP, Meijer CJ: Coexpression of Bmi-1 and EZH2 polycomb-group proteins is associated with cycling cells and degree of malignancy in Bcell non-Hodgkin lynphoma. Blood 2001, 97:3896-901.

13. Kim JH, Yoon SY, Jeong SH, Kim SY, Moon SK, Joo JH, Lee Y, Choe IS, Kim JW: Overexpression of Bmi-1 oncoprotein correlates with axillary lymph node metastases in invasive ductal breast cancer. Breast 2004, 13:383-388.

14. Kim JH, Yoon SY, Kim CN, Joo JH, Moon SK, Choe IS, Choe YK, Kim JW: The $\mathrm{Bmi}-1$ oncoprotein is overexpressed in human colorectal cancer and correlates with the reduced p16INK4a/p14ARF proteins. Cancer Letters 2004, 203:217-224.

15. Wang H, Pan K, Zhang HK, Weng DS, Zhou J, Li JJ, Huang W, Song HF, Chen MS, Xia JC: Increased polycomb-group oncogene Bmi-1 expression correlates with poor prognosis in hepatocellular carcinoma. Cancer Res Clin Oncol 2008, 134:535-541.

16. Zhang F, Sui L, Xin T: Correlations of Bmi-1 expression and telomerase activity in ovarian cancer tissues. Exp Oncol 2008, 30:70-74.

17. Mihara K, Chowdhury M, Nakaju N, Hidani S, Ihara A, Hyodo H, Yasunaga S, Takihara $Y$, Kimura A: Bmi-1 is useful as a novel molecular marker for predicting progression of myelodysplastic syndrome and prognosis of the patients. Blood 2006, 107:305-308.

18. Song LB, Zeng MS, Liao WT, Zhang L, Mo HY, Liu WL, Shao JY, Wu QL, Li MZ, Xia YF, Fu LW, Huang WL, Dimri DP, Band V, Zeng YX: Bmi-1 is a 
novel molecular marker of nasopharyngeal carcinoma progression and immortalizes primary human nasopharyngeal epithelial cells. Cancer Res 2006, 66:6225-6232.

19. Qin ZK, Yang JA, Ye YL, Zhang X, Xu LH, Zhou FJ, Han H, Liu ZW, Song LB, Zeng MS: Expression of Bmi-1 is a prognostic marker in bladder cancer. BMC Cancer 2009, 9:61.

20. Huang KH, Liu JH, Li XX, Song LB, Zeng MS: Association of Bmi-1 mRNA expression with differentiation, metastasis and prognosis of gastric carcinoma. Nan Fang Yi Ke Da Xue Bao 2007, 27:973-975.

21. Xie D, Sham JST, Zeng WF, Lin HL, Che LH, Wu HX, Wen JM, Fang Y, Hu L, Guan XY: Heterogeneous expression and association of $\beta$-catenin, p16 and c-myc in multistage colorectal tumorigenesis and progression detected by tissue microarray. Int I Cancer 2003, 107:896-902.

22. Xie D, Zeng YX, Wang HJ, Wen JM, Tao Y, Sham JS, Guan XY: Expression of cytoplasmic and nuclear Survivin in primary and secondary human glioblastoma. Br J Cancer 2006, 94:108-14.

23. Luo JH, Xie D, Liu MZ, Chen W, Liu YD, Wu GQ, Kung HF, Zeng YX, Guan XY: Protein expression and amplification of AIB1 in human urothelial carcinoma of the bladder and overexpression of AIB1 is a new independent prognostic marker of patient survival. Int J Cancer 2008, 122:2554-61

24. Lynch HT, Casey MJ, Lynch J, White TE, Godwin AK: Genetics and ovarian carcinoma. Semin Oncol 1998, 25:265-80.

25. Lessard J, Schumacher A, Thorsteinsdottir U, van Lohuizen M, Magnuson T, Sauvageau G: Functional antagonism of the Polycomb-Group genes eed and BMI1 in hemopoietic cell proliferation. Genes Dev 1999, 13:2691-2703.

26. Leung C, Lingbeek M, Shakhova O, Liu J, Tanger E, Saremaslani P, Van Lohuizen M, Marino S: BMI1 is essential for cerebellar development and is overexpressed in human medulloblastomas. Nature 2004, 428:337-341.

27. Bea S, Tort F, Pinyol M, Puig X, Hernández L, Hernández S, Fernandez PL, van Lohuizen M, Colomer D, Campo E: BMI-1 gene amplification and overexpression in hematological malignancies occur mainly in mantle cell lymphomas. Cancer Res 2001, 61:2409-2412.

28. Breuer RH, Snijders P, Sutedja GT, Sewalt RG, Otte AP, Postmus PE, Meijer CJ, Raaphorst FM, Smit EF: Expression of the p16(INK4a) gene product, methylation of the p16(INK4a) promoter region and expression of the polycomb-group gene BMI-1 in squamous cell lung carcinoma and premalignant endobronchial lesions. Lung Cancer 2005, 48:299-306.

29. Van Leenders GJ, Dukers D, Hessels D, van-den-Kieboom SW, Hulsbergen CA, Witjes JA, Otte AP, Meijer CJ, Raaphorst FM:

Polycombgroup oncogenes EZH2, BMI1, and RING1 are overexpressed in prostate cancer with adverse pathologic and clinical features. Eur Urol 2007, 52:455-63.

30. Stark GR, Debatisse M, Giulotto E, Wahl GM: Recent progress lunderstanding mechanisms of mammalian DNA amplification. Cell 1989, 57:901-8.

\section{Pre-publication history}

The pre-publication history for this paper can be accessed here: http://www.biomedcentral.com/1471-2407/10/133/prepub

doi:10.1186/1471-2407-10-133

Cite this article as: Yang et al:: Intensive expression of Bmi-1 is a new independent predictor of poor outcome in patients with ovarian carcinoma. BMC Cancer 2010 10:133.

\section{Submit your next manuscript to BioMed Central and take full advantage of:}

- Convenient online submission

- Thorough peer review

- No space constraints or color figure charges

- Immediate publication on acceptance

- Inclusion in PubMed, CAS, Scopus and Google Scholar

- Research which is freely available for redistribution

Submit your manuscript at www.biomedcentral.com/submit
Biomed Central 